\title{
USE OF CANGA AS DIMENSION STONE
}

\author{
Francielle Câmara Nogueira ' \\ Samara Santana Menezes ' \\ Mario Luis Cabello Russo ${ }^{2}$ \\ Carlos Alberto Pereira '
}

\begin{abstract}
Canga is a residual product resistant to mechanical weathering and practically inert chemical weather. The wide occurrence of this material in the region of Ouro Preto viability their use on behalf of the community and encourage studies about their physical and chemical properties. In this context, this pioneering research supporting the use of canga in the ornamental rock sector focus as dimension stone. The samples collected in geological site of Ouro Preto was characterized using x-ray diffraction, density and porosity determinations, Rockwell hardness test, Schmidt rebound hammer test and chemical analysis. The Schmidt rebound hammer tests were very efficient to detect internal imperfections, which was proven by the test of porosity. In addition, the fact of this test be non - destructive with easy realization makes their use viable, because there is no material lost. The performance of material compared with quartzite, usually used as dimension stone, was proved for this purpose. Its properties even suggest the application in other sectors such as ceramics and construction. Keywords: Canga; Characterization; Dimension stone.
\end{abstract}

\section{USO DA CANGA COMO ROCHA ORNAMENTAL}

\section{Resumo}

A canga é um produto residual resistente à meteorização mecânica e praticamente inerte ao intemperismo químico. A grande ocorrência desse material na região de Ouro Preto e a viabilização do seu uso em prol da comunidade incentivam o seu estudo e desperta o interesse em conhecer suas propriedades físicas e químicas. Nesse contexto, surge essa pesquisa pioneira fundamentando a utilização da Canga no setor de rochas ornamentais com enfoque na arte da Cantaria. As amostras coletadas no sítio geológico da região em estudo foram caracterizadas utilizando difratometria de raios-X, ensaios de massa específica e porosidade, determinação de dureza Rockwell e ensaios não destrutivos com o esclerômetro Schmidt. Os testes com o esclerômetro mostraram-se muito eficientes para detectar imperfeições internas na peça, o que foi comprovado pelo teste de porosidade. Além disso, o fato desse teste ser não destrutivo e de fácil realização torna a sua utilização viável, não ocorrendo perda de material. O desempenho do material no decorrer do estudo encoraja o seu prosseguimento, visto que, mediante correlação realizada com quartzito, usualmente utilizado como rocha ornamental, foi comprovada a configuração da canga para esta finalidade. Suas propriedades ainda sugerem a aplicação em outros setores como de cerâmica e construção civil.

Palavras-chave: Canga; Caracterização; Rocha ornamental.

\section{INTRODUCTION}

According to Araújo et al. [I] the various existing rocks present different characteristics that can be employed in different occasions. Therefore, the knowledge of the physical, mechanical, chemical properties of rocks enables their use.

The English mineralogist Mawe [2] named a red clay formation containing kaolinite, goethite, hematite and other minerals as tapanhocanga. In the case of Ouro Preto, the material presents a larger amount of limonite (mixture of hydrated iron oxide minerals) that increases the hardness of the formation and is called canga, which is generated by a lateritization process, where hydrated iron oxides are precipitated.

In the eighteenth century, canga was largely used for building retaining walls, housing structures, walls and other

'Departamento de Engenharia de Minas, Universidade Federal de Ouro Preto - UFOP, Ouro Preto, MG, Brazil. E-mail: franciellenoguera@yahoo.com.br ${ }^{2}$ Departamento de Edificações, Instituto Federal de Minas Gerais - IFMG, Ouro Preto, MG, Brazil. 
applications. However, in according the development of new materials in civil construction, especially concrete, in the nineteenth and twentieth centuries, replaced canga and the knowledge of its application was lost [3].

In order to encourage stonework with this regional rock, some effort has been done aiming to identify the characteristics of the canga to be used as raw material and the methods of applying it.

\section{MATERIALS AND METHODS}

Samples of canga were collected in the geological area of Ouro Preto and prepared for X-ray diffraction, density, porosity and water absorption determinations, Rockwell hardness, Schmidt rebound hammer, chemical analysis.

\section{I Tests to Determine Density, Porosity and Apparent Water Absorption}

In order to obtain density, porosity, and water absorption data (Equations I, 2 and 3), tests were carried out according to the Brazilian NBR I 2766 [4] standard using 10 (ten) cubes with edges of approximately 5 (five) $\mathrm{cm}$.

Apparent dry density:

$$
\rho_{\text {asec }}=\frac{A}{(B-C)}\left[\mathrm{kg} / \mathrm{m}^{3}\right]
$$

Apparent porosity:

$$
\eta_{a}=\frac{(B-A)}{(B-C)} * 100
$$

Apparent water absorption:

$$
\alpha_{a}=\frac{(B-A)}{A} * 100
$$

where: A - Oven-dry mass; B - Saturated surface dry mass; $C$ - Saturated submerged mass.

The values for the dry density, porosity and apparent water absorption are shown in Table I.

\subsection{Rockwell Hardness Tests}

The hardness obtained from the Rockwell hardness test (Figure I) is the resistance that the rock provides to the penetration of a hard body. The Rockwell method is based on the penetration depth of a tip.

To determine the Rockwell hardness, a Wolpert Rockwell hardness tester with a $1 / 4$ inch diameter sphere as

\begin{tabular}{|c|c|c|c|c|c|c|}
\hline \multirow{2}{*}{ SAMPLE } & \multicolumn{3}{|c|}{ Mass (g) } & \multirow{2}{*}{ Porosity (\%) } & \multirow{2}{*}{$\begin{array}{c}\text { Water } \\
\text { absorption }\end{array}$} & \multirow{2}{*}{ Dry Density } \\
\hline & (A) & (B) & (C) & & & \\
\hline $\mathbf{A}$ & 314 & 352 & 138 & 17.65 & 12.06 & 1.46 \\
\hline B & 324 & 363 & 143 & 17.79 & 12.05 & 1.48 \\
\hline C & 308 & 338 & 130 & 14.29 & 9.66 & 1.48 \\
\hline D & 361 & 399 & 149 & 15.05 & 10.42 & 1.44 \\
\hline $\mathbf{E}$ & 321 & 353 & 139 & 15.19 & 10.13 & 1.5 \\
\hline $\mathbf{F}$ & 244 & 263 & 147 & 16.41 & 7.77 & 2.28 \\
\hline G & 345 & 378 & 145 & 14.2 & 9.59 & 1.48 \\
\hline $\mathbf{H}$ & 296 & 337 & 135 & 20.24 & 13.79 & $\mathrm{I} .47$ \\
\hline $\mathbf{I}$ & 317 & 365 & 165 & 23.94 & 15.08 & 1.59 \\
\hline J & 322 & 356 & $|3|$ & $|5.0|$ & 10.46 & 1.43 \\
\hline
\end{tabular}
indenter was used. Faces that were approximately parallel

Table I. Values for apparent porosity, apparent water absorption and dry density

\begin{tabular}{|l|l|l|}
\hline 18.0 & 23.0 & 27.0 \\
24.5 & 26.0 & 21.0 \\
\hline & & \\
\hline 18.0 & 23.5 & 15.5 \\
24.5 & 31.0 & 14.5 \\
\hline & & \\
\hline 21.0 & 13.0 & 17.0 \\
18.0 & 23.5 & 14.0 \\
\hline
\end{tabular}

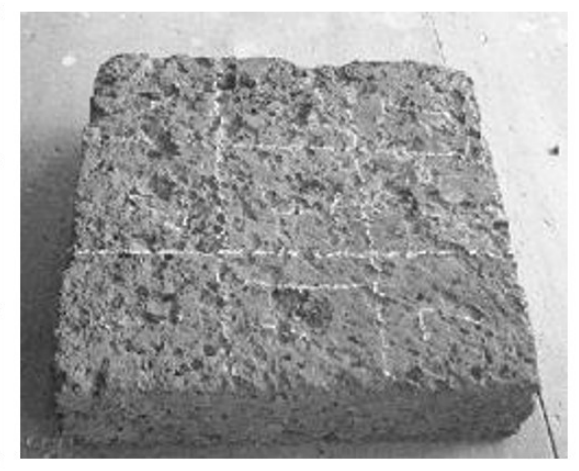

Figure I. Squared sample of canga. 
were chosen from each body. Ten ( 10$)$ hardness tests were performed. The results of the Rockwell test are shown in Table 2.

Segato et al. [5] determined the Rockwell hardness of quartzite, a dimension stone largely used in the region of Ouro Preto, obtaining values between 69 and 85 in the seventeen samples analyzed.

\subsection{Non Destructive Testing with the Schmidt Rebound Hammer Type N}

A non-destructive test was done with the Schmidt rebound hammer [6], type N, performed according to "ISRM Suggested method for determination of the Schmidt hammer rebound hardness".

At first, the integrity of the samples without visible cracks was checked, followed by a slight polishing of the surfaces. To avoid energy dissipation upon impact, the test points were chosen as far as possible from the sample borders. The obtained readings depended on restored and inserted energies, and are free of source errors, including those from angulation. The samples analyzed and the distribution of impact points in the samples are shown in Figures I and 2, as well as the values of $Q$ for each impact point (Equation 4).

$$
Q=100 * \frac{\text { Restored energy }}{\text { Inserted energy }}
$$

\subsection{X-ray Diffractometry}

By analyzing the XRD pattern generated by the canga samples, it was possible to identify the key minerals goethite, hollandite, pyrolusite, and hematite.

\subsection{Chemical Analysis}

After the mineralogical identification, a chemical analysis was done. The results are shown in Table 3.

Table 2. Values of Rockwell hardness for Canga

\begin{tabular}{|c|c|c|c|c|c|c|c|c|c|c|}
\hline \multirow{2}{*}{ Sample } & \multicolumn{10}{|c|}{ Test } \\
\hline & $I$ & 2 & 3 & 4 & 5 & 6 & 7 & 8 & 9 & 10 \\
\hline I & 88 & 95 & 89 & 93 & 87 & 89 & 88.5 & 85 & 91 & 91 \\
\hline 2 & 79 & 90 & 84 & 74 & 85 & 88 & 82 & 88 & 85 & 86 \\
\hline 3 & 91 & 93 & 88 & 88 & 93 & 86 & 93 & 91 & 83 & 91 \\
\hline 4 & 84 & 81 & 89 & 87 & 96 & 88 & 87 & 89 & 83 & 88.5 \\
\hline 5 & 88 & 91 & 91 & 88.5 & 94 & 93 & 92 & 88.5 & 91 & 93 \\
\hline 6 & 83 & 87 & 89 & 88 & 89 & 88 & 83 & 89 & 89 & 88 \\
\hline 7 & 79 & 86 & 89 & 83 & 82 & 90 & 86 & 88 & 92 & 86 \\
\hline 8 & 85 & 97 & 87 & 92 & 88 & 87 & 82 & 79 & 83 & 88 \\
\hline 9 & 73 & 75 & 91 & 87 & 80 & 82.5 & 76 & 80 & 78 & 87 \\
\hline 10 & 91 & 95 & 89 & 91 & 85 & 85 & 92 & 91 & 93 & 87 \\
\hline
\end{tabular}

Table 3. Content analysis of elements determined in chemical analysis

\begin{tabular}{|c|c|c|c|c|c|c|c|c|c|c|c|c|}
\hline $\mathrm{Fe}_{2} \mathrm{O}_{3}$ & MnO & $\mathrm{BaO}$ & $\mathrm{SiO}_{2}$ & $\mathrm{Al}_{2} \mathrm{O}_{3}$ & $\mathbf{P}_{2} \mathbf{O}_{5}$ & $\mathrm{~K}_{2} \mathrm{O}$ & $\mathrm{TiO}_{2}$ & MgO & $\mathrm{CaO}$ & PbO & $\mathrm{SO}_{3}$ & L.O.I (*) \\
\hline $45.3 \%$ & $35.4 \%$ & $6.0 \%$ & $1.2 \%$ & $1.0 \%$ & $0.1 \%$ & $0.1 \%$ & $0.1 \%$ & $<0.1 \%$ & $<0.1 \%$ & $<0.1 \%$ & $<0.1 \%$ & $10.6 \%$ \\
\hline
\end{tabular}

(*) L.O.I. - Loss on Ignition.

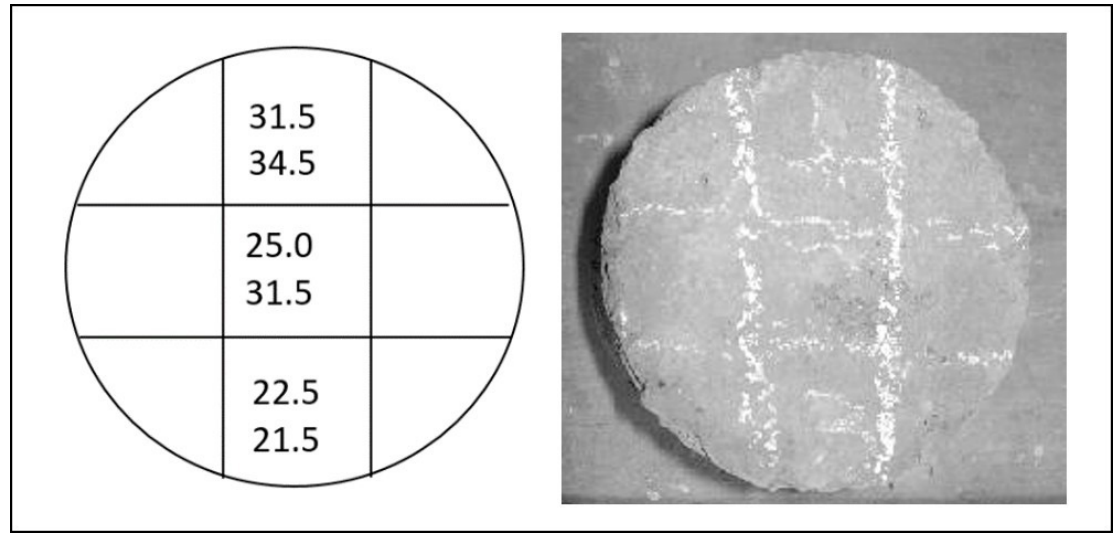

Figure 2. Cylindrical sample of canga. 


\section{CONCLUSIONS}

The porosity tests presented high values as expected, since the Canga is a residual product generated by the lixiviation of other components of the rock.

The relationship among the values for porosity, water absorption and dry density was clear. Pieces of canga extract could be separated according to separation class to be used in different applications. For example, in retaining walls, there was a physical interaction between the stones and the mortars (regardless of the mortar used) and as such, requires material with high absorption properties. On the other hand, in stonework such as floors and coverings, material with low absorption is desirable.

Tests with the Schmidt rebound hammer showed to be very effective to detect internal flaws in the piece, which was confirmed by the porosity test.

In a practical way, when using canga as raw material in stonework, tests with the Schmidt rebound hammer are effective for the selection of the pieces of canga that meet the specifications for each one of the applications. Low values of $\mathrm{Q}$ indicate fractures or very porous sites, and the test is nondestructive and easy to apply.

\section{REFERENCES}

I Araújo AMM, Sousa AA, Feitosa MCA, Oliveira GAR. Caracterização tecnológica do granito "Exótico Fuji" para usos ornamentais. Tecnologica em Metalurgia, Materiais e Mineração. 2015;12(3):25I-256.

2 Mawe J. Travel to Brazil, specifically the districts of gold and diamond in 1809-1810. Belo Horizonte: Official Press of Minas; 1922. $388 \mathrm{p}$.

3 Menicali UI. Materialidell'ediliziastorica: tecnologia e impiego dei materialitradizionali. Roma: La Nuova Itália Scientifica; 1992. 286 p.

4 Associação Brasileira de Normas Técnicas - ABNT. NBR 12766: rocks for covering: determination of the apparent specific density, apparent porosity and apparent absorption of water: method for tests. Rio de Janeiro; 1992.

5 Segato MC, Pereira CA., Luz JAM. Research, development and revival of stonework in Ouro Preto. Fundação de Amparo à Pesquisa do Estado de Minas Gerais; 2007.

6 International Society for Rock Mechanics and Rock Engineering - ISRM. ISRM suggested method for determination of the Schmidt hammer rebound hardness: revised version. Lisboa; 2008. p. 8.

Received: 6 Dec. 2016

Accepted: I May 2017 